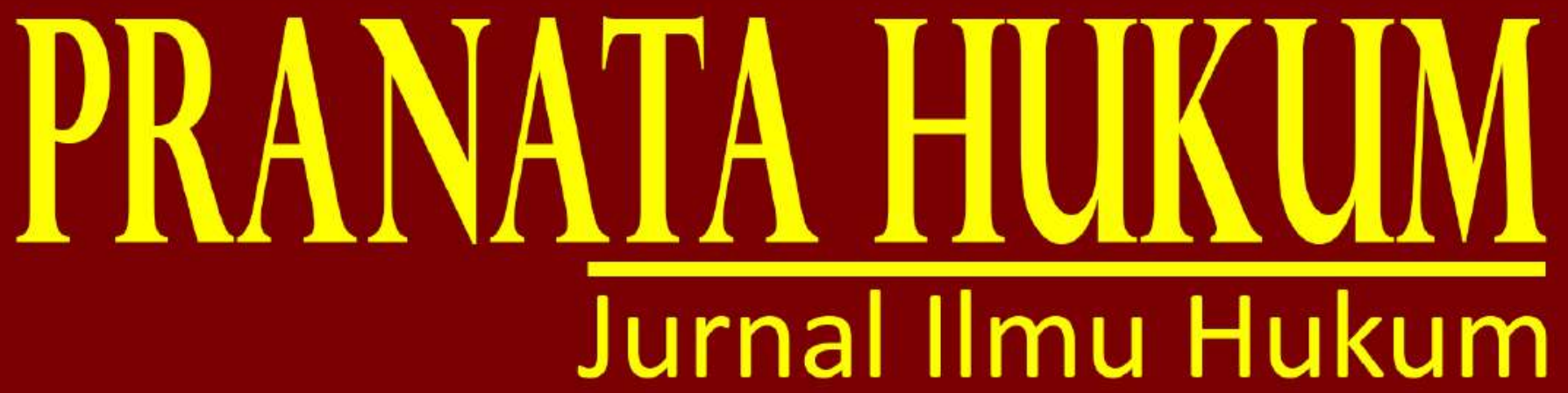

e-ISSN 2685-3213 | p-ISSN 1907-560X

SINERGITAS PEMERINTAHAN DESA DALAM PEMBENTUKAN PERATURAN DESA Anggalana

PENYELESAIAN SENGKETA PERBANKAN BERKAITAN DENGAN PERLINDUNGAN KONSUMEN Dian Herlambang, Muhammad Ridho Wijaya

ANALISIS KOMPARASI ANTARA PERLINDUNGAN PATEN BIASA DENGAN PATEN SEDERHANA BERDASARKAN UNDANG-UNDANG PATEN

Erlina, Melisa Safitri

KONSEPSI NEGARA HUKUM PANCASILA DAN IMPLEMENTASINYA DI INDONESIA Tubagus Muhammad Nasarudin

ANALISIS KEBIJAKAN PEMUNGUTAN RETRIBUSI PELAYANAN PERSAMPAHAN KEBERSIHAN DALAM RANGKA PENINGKATAN PENDAPATAN ASLI DAERAH DI KOTA BANDAR LAMPUNG Pertiwi Agustina RA, Lintje Anna Marpaung, Herlina Ratna Sumbawa Ningrum

ANALISIS KEDUDUKAN PERATURAN DESA PASCA PENGESAHAN UNDANG-UNDANG NOMOR 6 TAHUN 2014 TENTANG DESA DI DESA BADRAN SARI DAN NAMBAH REJO KABUPATEN LAMPUNG TENGAH

Baharudin, Indah Satria, Ramanda Ansori

FANATISME DAN EKSISTENSI NILAI-NILAI DEMOKRASI KADER NAHDLATUL ULAMA KOTA METRO PADA PILPRES 2019

Hendra Irawan, Ika Selviana

PERLINDUNGAN HUKUM TERHADAP PEMENANG LELANG BARANG RAMPASAN NEGARA BERUPA KENDARAAN RODA DUA YANG DIEKSEKUSI DENGAN CARA LELANG OLEH KEJAKSAAN

Okta Vianus Puspa Negara, Zainab Ompu Jainah, S. Tri Herlianto

ANALISIS PERTANGGUNGJAWABAN PELAKU TINDAK PIDANA MENGGANDAKAN SURAT PALSU UNTUK BEKERJA DI PT. GREAT GIANT PINEAPPLE HUMAS JAYA

Helmi Rangkuti, Ketut Seregig, Tami Rusli

MAGISTER HUKUM

UNIVERSITAS BANDAR LAMPUNG

\begin{tabular}{c|c|c|c|l}
$\begin{array}{c}\text { PRANATA } \\
\text { HUKUM }\end{array}$ & $\begin{array}{c}\text { Volume } \\
15\end{array}$ & $\begin{array}{c}\text { Nomor } \\
1\end{array}$ & $\begin{array}{c}\text { Halaman } \\
1-119\end{array}$ & $\begin{array}{l}\text { Bandar } \\
\text { Lampung } \\
\text { Januari } 2020\end{array}$ \\
\hline
\end{tabular}




\section{PRANATA HUKUM}

Jurnal Ilmu Hukum

Magister Hukum

Universitas Bandar Lampung

Terbit Pertama Kali, Juli 2006

Terbit Dua Kali Setahun, Setiap Januari dan Juli

EDITOR IN-CHIEF

Prof. Dr. Lintje Anna Marpaung, S.H., M.H

EDITORIAL BOARDS MEMBERS

Dr. Bambang Hartono, S.H., M.Hum

Dr. Tami Rusli, S.H., M.Hum

Dr. Erlina B, S.H., M.H

Dr. Zainab Ompu Jainah, S.H., M.H

Dr. Zulfi Diane Zaini, S.H., M.H

MANAGING EDITOR

Indah Satria, S.H., M.H

ASSISTANT EDITORS

Yulia Hesti, S.H., MH

Shany Carolina Mawuntu

\section{PENYUNTING AHLI (MITRA BESTARI)}

Prof. Dr. I Gusti Ayu Ketut Rachmi Handayani, S.H., M.M (Universitas Sebelas Maret)

Prof. Dr. I Gede A.B Wiranata, S.H., M.H (Universitas Lampung)

Dr. Nurhadiantomo, S.H., M.Hum (Universitas Muhammdiyah Surakarta)

Dr. Erina Pane, S.H., M.H (UIN Lampung)

\section{Alamat: \\ Kampus B Universitas Bandar Lampung}

Jl. Z.A Pagar Alam No.89 Labuhan Ratu, Bandar Lampung 35142

Telp: 0721-789825 Fax: 0721-770261

Email: jurnal.mh@ubl.ac.id

Jurnal PRANATA HUKUM dimaksudkan sebagai media komunikasi ,edukasi dan informasi ilmiah bidang ilmu hukum. Sajian dan kemasan diupayakan komunikatif melalui bahasa ilmiah.

Redaksi mengundang semua elemen masyarakat ,baik civitas akademika, praktisi , lembaga masyarakat, maupun perorangan yang berminat terhadap bidang hukum untuk berpartisipasi mengembangkan gagasan, wawasan, dan pengetahuan melalui tulisan untuk dimuat dalam jurnal ini. Melalui PRANATA HUKUM diharapkan terjadi proses pengembangan bidang hukum sebagai bagian penting dari rangkaian panjang proses memajukan masyarakat bangsa 


\title{
ANALISIS PERTANGGUNGJAWABAN PELAKU TINDAK PIDANA MENGGANDAKAN SURAT PALSU UNTUK BEKERJA DI PT. GREAT GIANT PINEAPPLE HUMAS JAYA
}

\author{
Helmi Rangkuti, Ketut Seregig, Tami Rusli
}

\begin{abstract}
The rise of the crime of counterfeit letters is very concern for people who become victims of crime and the emergence of the crime is racing because the perpetrators want a profit. All the criminal counterfeiting of the letter is very large both for the victims and other communities by the loss of both material and non-material, in the life of this advanced society and regularly want a guarantee of truth on the evidence of a letter owned by a person. The research result is the cause of perpetrators of criminal acts doubling the counterfeit letter to work at PT Great Giant Pineapple Humas Jaya in article No. 403/Pid. B/2018/PN. Gns namely intention perpetrator, low education factor, factors of economic necessity, and the low Moral factor and religious knowledge, the liability of perpetrators of criminal acts doubling the false letter to work in verdict number: 403/Pid. B/2018/PN. Gns adjusted to the decision of the Assembly of judges that the perpetrators proved lawfully and conclusive criminal acts doubling the counterfeit letter to work with imprisonment for 1 (one) year
\end{abstract}

Keywords: criminal liability; doubling of false letters

\section{PENDAHULUAN}

Maraknya kejahatan pemalsuan surat yang terjadi saat ini sangat memprihatinkan bagi masyarakat yang menjadi korban kejahatan dan munculnya kejahatan tersebut terpacu karena para pelaku menginginkan keuntungan. Berdasarkan data yang dipublikasikan oleh Kepolisian Polda Lampung Tahun 2018, tercatat tindak pidana pemalsuan surat yang terjadi di wilayah hukum Polda Lampung sebanyak sepuluh kasus. Semua kejahatan pemalsuan surat tersebut implikasinya sangat besar baik bagi yang menjadi korban maupun masyarakat lainnya dengan mengalami kerugian baik materiil maupun non material, di dalam kehidupan masyarakat yang sudah maju ini dan teratur menginginkan adanya jaminan kebenaran atas bukti surat dimiliki oleh seseorang. Untuk membuktikan pemalsuan tanda tangan korban atas perbuatan pelaku korban harus melapor ke Polisi dengan membawa bukti surat yang asli dan bukti surat yang dipalsukan tersebut sehingga atas dasar Laporan Polisi tersebut pihak Penyidik akan melakukan penyelidikan dan penyidikan atas adanya surat palsu.

Pengaturan hukum yang demikian, dapat diketahui perbuatan-perbuatan yang melawan hukum dan dapat diketahui pula alasannya seseorang untuk melakukan perbuatan yang melawan hukum, sehingga dapat menimbulkan reaksi 
sosial pada masyarakat. Reaksi sosial dapat pula dikatakan sebagai usaha mencapai tata tertib sosial, bentuk reaksi sosial ini akan semakin nampak pada saat persoalanpersoalan dan ancaman kejahatan meningkat secara kuantitas dan kualitas. Pengendalian sosial melalui hukum ini akan menghadapkan individu atau anggota masyarakat pada alternatif pilihan yaitu penyesuaian atau penyimpangan, sedangkan dalam bentuk penyimpangan atau pelanggaran yang paling serius sifatnya adalah pelanggaran hukum pidana yang disebut kejahatan. Surat adalah segala surat, baik yang ditulis dengan tangan, dicetak, maupun ditulis memakai mesin tik, dan lain-lainnya. Surat yang dipalsukan itu harus surat yang dapat menimbulkan sesuatu hak (misalnya: ijazah, karcis tanda masuk, surat andil, dan lain-lain); 2. dapat menerbitkan suatu perjanjian (misalnya surat perjanjian piutang, perjanjian jual beli, perjanjian sewa, dan sebagainya); 3 . dapat menerbitkan suatu pembebasan hutang (kuitansi atau surat semacam itu); atau 4. surat yang digunakan sebagai keterangan bagi suatu perbuatan atau peristiwa (misalnya surat tanda kelahiran, buku tabungan pos, buku kas, buku harian kapal, surat angkutan, obligasi, dan lain-lain) (R. Soesilo. 1991:195).

Pemakaian surat palsu yang dilakukan pelaku dalam tindak pidana pemalsuan surat tidak harus dapat mendatangkan kerugian tidak perlu kerugian itu nyata atau benar ada baru kemungkinan saja akan adanya kerugian itu sudah cukup menjerat pelaku pemalsuan surat yang diartikan kerugian disini tidak saja hanya meliputi kerugian materiil akan tetapi juga kerugian imaterial dimasyarakat, kesusilaan, kehormatan dan sebagainya. Beberapa waktu yang lalu kasus pemalsuan surat juga pernah di tangani oleh Polres Lampung Tengah yang juga telah mendapatkan vonis Hakim yang berkekuatan hukum tetap. Adapun perkara tersebut terdapat dalam putusan Pengadilan Nomor 403/Pid.B/ 2018/PN.Gns. Bahwa dalam putusan tersebut terdapat kronologis kejadian yakni sebagai berikut:

Pada waktu dan tempat sebagai mana diuraikan diatas, berawal dari saksi Amrusi Bin E.R. Abdullah. S (Anggota Polri) mendapat informasi dari masyarakat bahwa ada konter pulsa yang dapat membuat Surat Keterangan Catatan Kepolisian (SKCK), berdasarkan informasi tersebut saksi Amrusi Bin E.R. Abdullah. S bersama dengan anggota Polri lainnya melakukan penyelidikan dimana konter pulsa tersebut dan didapatkan keberadaan konter pulsa tersebut yaitu di Dusun Kecubung Rt/Rw 001/004 Desa Terusan Nunyai Kecamatan Terusan Nunyai Kabupaten Lampung Tengah, selanjutnya pada hari kamis tanggal 27 September 2018 saksi bersama dengan anggota Reskrim berpura - pura sebagai pelanggan yang ingin dibuatkan SKCK untuk melamar pekerjaan kepada Terdakwa M SOLIKHIN Bin LASIMIN kemudian Terdakwa bersedia untuk membuat SKCK dengan harga Rp.25.000.000,- (dua puluh lima ribu rupiah), mengetahui hal tersebut kemudian saksi Amrusi Bin E.R. Abdullah. S bersama dengan anggota Polri lainnya melakukan penagkapan terhadap Terdakwa. 
Kemudian diamankan ke Polsek Terusan Nunyai, setelah dilakukan pemeriksaan, Terdakwa mengakui telah memalsukan SKCK sejak bulan Nopember 2017 sampai dengan Terdakwa ditangkap pada pada hari Kamis tanggal 27 September 2018 sekira pukul 21.00 WIB dan Terdakwa telah mencetak SKCK palsu kurang lebih 45(empat puluh lima) lembar dan cara terdakwa memalsukan SKCK adalah dengan memperbanyak foto copy SKCK yang asli yang masa berlakunya habis kemudian foto copy SKCK di scaner di printer milik Terdakwa lalu Terdakwa mengedit dan mengganti tahun serta tanggal masa berlaku SKCK tersebut, setelah tahun dan masa berlakunya diganti lebar SKCK diprint menjadi beberapa lembar, sehingga tercetak foto copy SKCK dengan tanggal bulan dan tahun yang sudah diperpanjang oleh Terdakwa dan SKCK yang telah dicetak/dipalsukan oleh Terdakwa antara lain adalah milik saksi I Made Budi Wicaksono dan milik saksi Woro Septia Ningsih.; Perbuatan terdakwa M SOLIKHIN Bin LASIMIN sebagaimana diatur dan diancam pidana dalam pasal 263 ayat (1) K.U.H.Pidana.;

Adanya suatu kejadian pemalsuan surat untuk bekerja menyebabkan kerugian material dan sosial yang tidak sedikit bagi korban maupun keluarganya. Oleh karena itu butuh adanya suatu pertanggungjawaban hukum bagi para pelaku yang melakukan tindak pidana menggandakan surat palsu untuk bekerja. Berdasarkan uraian latar belakang yang telah dikemukakan diatas, dapat di kemukakan permasalahan sebagai berikut: a. Apakah yang menjadi faktor penyebab pelaku melakukan tindak pidana pemalsuan surat untuk bekerja Di PT Great Giant Pineapple Humas Jaya dalam Putusan Nomor 403/Pid.B/2018/PN.Gns? b. Bagaimanakah pertanggungjawaban pelaku tindak pidana pemalsuan surat untuk bekerja Di PT Great Giant Pineapple Humas Jaya dalam Putusan Nomor 403/Pid.B/2018/PN.Gns? Permasalahan yang terdapat dalam penelitian proposal tesis ini, peneliti melakukan dua pendekatan yaitu melalui pendekatan yuridis normatif dan pendekatan empiris guna untuk mendapatkan suatu hasil penelitian yang benar dan objektif.

\section{II.PEMBAHASAN}

\section{A. Faktor penyebab pelaku menggandakan surat palsu untuk bekerja Di PT Great Giant Pineapple Humas jaya pada putusan Nomor : 403/Pid.B/ 2018/PN. GNS)}

Pengertian tindak pidana dalam Kitab Undang-Undang Hukum Pidana (KUHP) dikenal dengan istilah stratbaar feit.Tindak Pidana itu sendiri adalah perbuatan yang dilarang oleh suatu aturan hukum, larangan mana disertai ancaman (sanksi) yang berupa pidana tertentu bagi barang siapa yang melanggar larangan tersebut.Tindak pidana merupakan pengertian dasar dalam hukum pidana (yuridis normatif). Kejahatan atau perbuatan jahat dapat diartikan secara yuridis atau kriminologi. Kejahatan atau perbuatan jahat dalam arti yuridis 
normatif adalah perbuatan seperti yang terwujud in-abstracto dalam peraturan pidana, sedangkan kejahatan dalam arti kriminologi adalah perbuatan manusia yang menyalahi norma yang hidup di masyarakat secara konkrit.

Faktor penyebab pelaku untuk melakukan perbuatan memalsukan surat untuk bekerja Di PT Great Giant Pineapple Humas jaya terdorong oleh keinginan nya bekerja pada perusahaan PT Great Giant Pineapple Humas jaya. Hal ini dinyatakan oleh penyidik polres Lampung Tengah Iptu Nano Taryono dalam wawancara pada hari Senin Tanggal 9 Desember 2019 yang menyatakan bahwa Pelaku melakukan tindak pidana memalsukan surat untuk bekerja Di PT Great Giant Pineapple Humas jaya terdorong oleh keinginan pelaku untuk bekerja pada perusahaan PT Great Giant Pineapple Humas jaya dan juga kesulitan memperoleh pekerjaan.

Tindak pidana sendiri semakin hari semakin marak terjadi dan berkembang semakin cepat di kehidupan masyarakat. Hal tersebut tidak lepas dari berbagai aspek seperti aspek sosial, lingkungan,dan aspek lainnya khususnya pada aspek ekonomi. Salah satu objek tindak pidana yang ada yaitu tindak pidana pemalsuan surat. Perbuatan yang dilakukan oleh pelaku dalam memalsukan surat untuk bekerja Di PT Great Giant Pineapple Humas jaya tersebut diatas menurut Iptu Nano Taryono selaku penyidik polres Lampung Tengah telah memenuhi Pasal 263 ayat (1) KUHP yang berbunyi "Barang siapa membuat surat palsu atau memalsukan surat yang dapat menimbulkan sesuatu hak, perikatan atau pembebasan hutang, atau yang diperuntukkan sebagai bukti daripada sesuatu hal dengan maksud untuk memakai atau menyuruh orang lain memakai surat tersebut seolah-olah isinya benar dan tidak dipalsu, diancam jika pemakaian tersebut dapat menimbulkan kerugian, karena pemalsuan surat, dengan pidana penjara paling lama enam tahun".

Menurut Iptu Nano Taryono selaku penyidik polres Lampung Tengah bahwa terdakwa dalam proses peradilan dinilai mampu bertanggung jawab karena ketika dalam proses persidangan di pengadilan terdakwa terlihat sehat, mampu menjawab setiap pertanyaan hakim yang disampaikan kepada terdakwa dan menunjukkan prilaku tenang dalam konteks pisik yang sehat baik secara jasmani maupun rohani. Berdasarkan teori pertanggungjawaban pidana oleh Roeslan Saleh yang menyatakan bahwa : "seseorang dinyatakan jiwanya sehat dan mampu bertanggungjawab,dia mampu untuk mengetahui atau menyadari bahwa perbuatannya tersebut bertentangan dengan hukum dan ia dapat menyatakan kehendak sesuai dalam ketentuan tersebut".

Iptu Nano Taryono selaku penyidik polres Lampung Tengah mengatakan bahwa Tindak pidana pemalsuan surat merupakan tindak pidana yang cukup meresahkan masyarakat, karena niat pelaku yang terencana dan tersusun rapi sehingga sulit untuk dilacak. Hal inilah yang membuat pemalsuan diatur dan termasuk suatu tindakan pidana.Tindak pidana pemalsuan pada umumnya 
dilakukan oleh pelaku yang memiliki kewenangan dalam suatu kumpulan masyarakat, lembaga atau instansi dan organisasi pemerintahan. Dalam hal pemalsuan surat tersebut dapat berupa pemalsuan tanda tangan dan pemalsuan surat keterangan cari kerja atau SKCK yang dilakukan oleh pelaku dengan cara mengubah surat asli sedemikian rupa, sehingga isinya menjadi lain dari aslinya.

Dwi Aviandari selaku Hakim pada Pengadilan Negeri Gunung Sugih menyebutkan bahwa faktor penyebab seseorang melakukan tindak pidana dapat dibagi menjadi beberapa faktor diantaranya : 1. Individual (antropologis) yang meliputi: usia, seks atau jenis kelamin, status sipil, profesi atau pekerjaan, tempat tinggal/domisili, tingkat sosial, pendidikan, konstitusi organis dan psikis. 2. Fisik (natural, alam): ras, suku, iklim, fertilitas, disporsisi bumi, keadaan alam diwaktu malam hari dan siang hari, musim, kondisi meteoric atau keruang angkasaan, kelembaban udara dan suhu. 3. Sosial: antara lain: kepadatan penduduk, susunan masyarakat, adat istiadat, agama, orde pemerintah. 4. Kondisi ekonomi dan indutri, pendidikan, jaminan social, lembaga legislative dan lembaga hukum, dan lain-lain.

Kemudian menurut Dwi Aviandari bahwa seseorang yang melakukan suatu tindak pidana bukan hanya didasarkan pada niat pelaku itu sendiri namun didasarkan oleh faktor lain seperti faktor kesempatan, dalam tindak pidana dalam perkara ini faktor kesempatan itu sendiri sangat dominan dikarenakan tanpa adanya kesempatan segala tindak pidana tersebut tidak akan terjadi. Keterangan hakim diperkuat oleh jaksa yang menyatakan bahwa dalam dakwaan awal yang disampaikan oleh jaksa. Elva Yulita selaku Jaksa pada Kejaksaan Negeri Gunung Sugih menyatakan bahwa terdakwa dalam kondisi sehat jasmani dan rohani yang dinyatakan dalam berita acara pemeriksaan tersangka yang dibuat penyidik pada Polres Lampung Tengah.

Adapun kronologis tindak pidana menggandakan surat palsu untuk bekerja adalah sebagai berikut : Berawal dari saksi Amrusi Bin E.R. Abdullah. S (Anggota Polri) mendapat informasi dari masyarakat bahwa ada konter pulsa yang dapat membuat Surat Keterangan Catatan Kepolisian (SKCK), berdasarkan informasi tersebut saksi Amrusi Bin E.R. Abdullah. S bersama dengan anggota Polri lainnya melakukan penyelidikan dimana konter pulsa tersebut dan didapatkan keberadaan konter pulsa tersebut yaitu di Dusun Kecubung Rt/Rw 001/004 Desa Terusan Nunyai Kecamatan Terusan Nunyai Kabupaten Lampung Tengah, selanjutnya pada hari kamis tanggal 27 September 2018 saksi bersama dengan anggota Reskrim berpura - pura sebagai pelanggan yang ingin dibuatkan SKCK untuk melamar pekerjaan kepada Terdakwa M SOLIKHIN Bin LASIMIN kemudian Terdakwa bersedia untuk membuat SKCK dengan harga Rp.25.000.000,- (dua puluh lima ribu rupiah), mengetahui hal tersebut kemudian saksi Amrusi Bin E.R. Abdullah. S bersama dengan anggota Polri lainnya melakukan penagkapan terhadap Terdakwa. diamankan ke Polsek Terusan Nunyai, setelah dilakukan 
pemeriksaan, Terdakwa mengakui telah memalsukan SKCK sejak bulan Nopember 2017 sampai dengan Terdakwa ditangkap pada pada hari Kamis tanggal 27 September 2018 sekira pukul 21.00 WIB dan Terdakwa telah mencetak SKCK palsu kurang lebih 45(empat puluh lima) lembar dan cara terdakwa memalsukan SKCK adalah dengan memperbanyak foto copy SKCK yang asli yang masa berlakunya habis kemudian foto copy SKCK di scaner di printer milik Terdakwa lalu Terdakwa mengedit dan mengganti tahun serta tanggal masa berlaku SKCK tersebut, setelah tahun dan masa berlakunya diganti lebar SKCK diprint menjadi beberapa lembar, sehingga tercetak foto copy SKCK dengan tanggal bulan dan tahun yang sudah diperpanjang oleh Terdakwa dan SKCK yang telah dicetak/dipalsukan oleh Terdakwa antara lain adalah milik saksi I Made Budi Wicaksono dan milik saksi Woro Septia Ningsih.; Perbuatan terdakwa M SOLIKHIN Bin LASIMIN sebagaimana diatur dan diancam pidana dalam pasal 263 ayat (1) K.U.H.Pidana.;

Berdasarkan keterangan-keterangan diatas yang disampaikan oleh Iptu Nano Taryono selaku penyidik polres Lampung Tengah dan Dwi Aviandari selaku Hakim pada Pengadilan Negeri Gunung Sugih yaitu Bahwa penyebab pelaku melakukan tindak pidana pemalsuan surat pada kantor PT Great Giant Pineapple Humas jaya karena terdorong oleh keinginan pelaku untuk bekerja pada perusahaan PT Great Giant Pineapple Humas jaya, dan juga kesulitan memperoleh pekerjaan, kemudian kehidupan keluarga yang pas-pasan.

Hal ini sesuai dengan teori yang dikemukakan oleh JE Sahetapy yang menyatakan bahwa "faktor penyebab tindak pidana adalah pendekatan sobural, yaitu akronim dari nilai-nilai sosial, aspek budaya, dan faktor struktur yang merupakan elemen- elemen yang terdapat dalam setiap masyarakat. Aspek budaya dan faktor struktural merupakan dua elemen yang saling berpengaruh dalam masyarakat". Pendapat ini juga didukung oleh pendapat Momon Karta Saputra yang menyatakan bahwa "faktor-faktor yang menyebabkan seseorang melakukan kejahatan, yaitu Faktor internal diantaranya sifat khusus dari individu, seperti : sakit jiwa, daya emosional, rendahnya mental dan anomi dan sifat umum dari individu, seperti : umur, gender, kedudukan didalam masyarakat, pendidikan dan hiburan. Kemudian faktor eksternal diantaranya faktor ekonomi, lingkungan, agama, dan keluarga”.

\section{B. Pertanggungjawaban Pelaku Tindak Pidana Menggandakan Surat Palsu Untuk Bekerja Di PT Great Giant Pineapple Humas jaya dalam Putusan Nomor 403/Pid.B/2018/PN.Gns}

Dalam hal pertanggungjawaban pidana, sejak proses penyidikan sampai kepada proses pemeriksaan terdakwa dipengadilan bahwa pelaku harus memenuhi syarat sebagai orang yang mampu bertanggungjawab atas perbuatan yang dilakukannya. Hasil wawancara dengan Iptu Nano Taryono selaku penyidik 
polres Lampung Tengah menyatakan bahwa pelaku dianggap mampu bertanggung jawab atas kesalahan yang dilakukannya hal ini sudah saya tuangkan dalam Berita Acara Pemeriksaan (BAP) tersangka pada point yang menyatakan bahwa tersangka pada saat diperiksa dalam keadaan sehat jasmani dan rohani. Demikian juga dalam BAP tersangka mengakui secara sadar bahwa tersangka melakukan perbuatan tersebut semata-mata hanya ingin mendapatkan pekerjaan dan pada saat melakukan perbuatan tersebut tersangka tertangkap tangan.

Pertanggungjawaban pidana timbul ketika adanya suatu perbuatan pidana. Pertanggungjawaban pidana bukan bagian dari istilah perbuatan pidana tetapi memiliki hubungan yang erat dengan perbuatan pidana."Perbuatan pidana merupakan perbuatan yang dilarang oleh suatu aturan hukum larangan mana disertai ancaman (sanksi) yang berupa pidana tertentu,bagi siapa yang melanggar larangan tersebut." Melanggar perbuatan yang dilarang oleh suatu aturan hukum menimbulkan suatu dampak yakni kesalahan.Kesalahan yang dilanggar mempunyai konsekuensi bahwa perbuatan tersebut harus dapat dipertanggungjawabkan. Pertanggungjawaban pidana tidak dapat dilaksanakan jika tidak memiliki suatu kesalahan.Hal ini dinyatakan di dalam asas hukum pidana yakni Tidak dipidana,jika tidak ada suatu kesalahan (Geen straf zonder shuld;Actus non facit reum nisi mens sist rea). Dalam hal pertanggungjawaban pidana, sejak proses penyidikan sampai kepada proses pemeriksaan terdakwa dipengadilan bahwa pelaku harus memenuhi syarat sebagai orang yang mampu bertanggungjawab atas perbuatan yang dilakukannya. Hasil wawancara dengan Iptu Nano Taryono selaku penyidik polres Lampung Tengah menyatakan bahwa pelaku dianggap mampu bertanggung jawab atas kesalahan yang dilakukannya hal ini sudah saya tuangkan dalam Berita Acara Pemeriksaan (BAP) tersangka pada point yang menyatakan bahwa tersangka pada saat diperiksa dalam keadaan sehat jasmani dan rohani. Demikian juga dalam BAP tersangka mengakui secara sadar bahwa tersangka melakukan perbuatan tersebut semata-mata hanya ingin mendapatkan pekerjaan dan pada saat melakukan perbuatan tersebut tersangka tertangkap tangan.

Menurut Dwi Aviandari selaku Hakim pada Pengadilan Negeri Gunung Sugih bahwa pertanggungjawaban pidana adalah suatu perbuatan yang tercela oleh masyarakat yang harus dipertanggungjawabkan pada sipembuatnya atas perbuatan yang dilakukan. Pada hal tersebut maka tentu sipembuatnya dipidana. Suatu perbuatan melawan hukum belum cukup untuk menjatuhkan hukuman. Di samping melawan perbuatan melawan hukum harus ada seseorang pembuat (dader) yang bertanggungjawab atas perbuatannya. Pembuat (dader) harus ada unsur kesalahan (schuldhebben), bersalah itu adalah pertanggungjawaban dan harus ada dua unsur yang sebelumnya harus dipenuhi: a. Suatu perbuatan yang melawan hukum (unsur melawan hukum) b. Seorang pembuat atau pelaku yang di anggap mampu bertanggungjawab atas perbuatannya (unsur kesalahan). 
Menurut Elva Yulita selaku Jaksa pada Kejaksaan Negeri Gunung Sugih mengatakan sanksi pidana merupakan penjatuhan hukuman yang diberikan kepada seseorang yang dinyatakan bersalah dalam melakukan perbuatan pidana. Jenis-jenis pidana ini sangat bervariasi, seperti pidana mati, pidana seumur hidup, pidana penjara, pidana kurungan dan pidana denda yang merupakan pidana pokok, dan pidana pencabutan hak- hak tertentu, perampasan barang-barang tertentu, dan pengumuman putusan hakim yang kesemuanya merupakan pidana tambahan. Tujuan dari sanksi pidana adalah untuk mempertahankan ketertiban masyarakat, dan mempunyai tujuan kombinasi untuk menakutkan, memperbaiki dan untuk kejahatan tertentu membinasakan. Berdasarkan ketentuan Standar Operasional Prosedur (SOP) dalam penuntutan, maka syarat utama adalah pelaku sehat jasmani dan rohani, berdasarkan syarat kesehatan tersebut maka saya menilai bahwa terdakwa dianggap mampu bertanggungjawab. Keteranganketerangan yang disampaikan oleh terdakwa di persidangan terungkap bahwa dalam pemeriksaan sehat jasmani dan rohani, hal ini tertuang dalam putusan yang menyatakan sebagai berikut : Berawal dari saksi Amrusi Bin E.R. Abdullah. S (Anggota Polri) mendapat informasi dari masyarakat bahwa ada konter pulsa yang dapat membuat Surat Keterangan Catatan Kepolisian (SKCK), berdasarkan informasi tersebut saksi Amrusi Bin E.R. Abdullah. S bersama dengan anggota Polri lainnya melakukan penyelidikan dimana konter pulsa tersebut dan didapatkan keberadaan konter pulsa tersebut yaitu di Dusun Kecubung Rt/Rw 001/004 Desa Terusan Nunyai Kecamatan Terusan Nunyai Kabupaten Lampung Tengah, selanjutnya pada hari kamis tanggal 27 September 2018 saksi bersama dengan anggota Reskrim berpura - pura sebagai pelanggan yang ingin dibuatkan SKCK untuk melamar pekerjaan kepada Terdakwa M SOLIKHIN Bin LASIMIN kemudian Terdakwa bersedia untuk membuat SKCK dengan harga Rp.25.000.000,- (dua puluh lima ribu rupiah), mengetahui hal tersebut kemudian saksi Amrusi Bin E.R. Abdullah. S bersama dengan anggota Polri lainnya melakukan penagkapan terhadap Terdakwa. kemudian diamankan ke Polsek Terusan Nunyai, setelah dilakukan pemeriksaan, Terdakwa mengakui telah memalsukan SKCK sejak bulan Nopember 2017 sampai dengan Terdakwa ditangkap pada pada hari Kamis tanggal 27 September 2018 sekira pukul 21.00 WIB dan Terdakwa telah mencetak SKCK palsu kurang lebih 45(empat puluh lima) lembar dan cara terdakwa memalsukan SKCK adalah dengan memperbanyak foto copy SKCK yang asli yang masa berlakunya habis kemudian foto copy SKCK di scaner di printer milik Terdakwa lalu Terdakwa mengedit dan mengganti tahun serta tanggal masa berlaku SKCK tersebut, setelah tahun dan masa berlakunya diganti lebar SKCK diprint menjadi beberapa lembar, sehingga tercetak foto copy SKCK dengan tanggal bulan dan tahun yang sudah diperpanjang oleh Terdakwa dan SKCK yang telah dicetak/dipalsukan oleh Terdakwa antara lain adalah milik saksi I Made Budi Wicaksono dan milik saksi Woro Septia Ningsih.; Perbuatan terdakwa M SOLIKHIN 
Bin LASIMIN sebagaimana diatur dan diancam pidana dalam pasal 263 ayat (1) K.U.H.Pidana.;

Menurut Dwi Aviandari selaku Hakim pada Pengadilan Negeri Gunung Sugih bahwa Majelis Hakim dalam perkara tersebut memiliki beberapa pertimbangan pertimbangan hukum dalam memutus perkara tersebut. Adapun pertimbangannya di dasarkan dari alat-alat bukti yang telah diungkap dipersidangan diantaranya yaitu: 1. Unsur Barang Siapa Bahwa menurut Hukum Pidana Indonesia yang dimaksud dengan Unsur Barang Siapa adalah subjek siapa saja, baik subjek hukum laki-laki maupun subjek hukum perempuan yang sehat jasmani dan rohaninya serta dapat dipertanggung jawabkan atas perbuatannya ; Bahwa terdakwa dipersidangan pada pokoknya membenarkan bahwa keseluruhan identitasnya yang tercantum dalam dakwaan Penuntut Umum adalah benar diri terdakwa, demikian pula beberapa saksi pada pokoknya telah membenarkan bahwa yang dimaksud dengan M. SOLIKHIN Bin LASIMIN yang saat ini dihadapkan, diperiksa dan diadili di persidangan Pengadilan Negeri Gunung Sugih adalah benar diri terdakwa;

Bahwa di persidangan telah ternyata pula bahwa terdakwa adalah orang yang sehat jasmani dan rohaninya, yang berarti terdakwa adalah orang yang cakap dan mampu bertanggung jawab atas setiap perbuatan yang dilakukannya; Bahwa dengan demikian menjadi jelas bahwa yang dimaksud dengan unsur Barang Siapa ini adalah diri terdakwa sebagai subjek hukum, karena itu unsur pertama dari pasal ini telah terpenuhi Unsur "Membuat secara tidak benar atau memalsu surat yang dapat menimbulkan sesuatu hak, perikatan atau pembebasan hutang, atau yang diperuntukan sebagai bukti daripada sesuatu hal, dengan maksud untuk memakai atau menyuruh orang lain pakai surat tersebut seolah - olah isinya benar dan tidak dipalsu, diancam, jika pemakai tersebut dapat menimbulkan kerugian, karna pemalsuan surat."

Bahwa berdasarkan fakta-fakta dipersidangan terungkap bahwa terdakwa telah memalsukan Surat Keterangan Catatan Kepolisian (SKCK) yang diterbitkan dari Kepolisian Resort Lampung Tengah dan ditandatangani Kasat Intelkam HERU SULISTYANANTO, S.H yang dilakukan Terdakwa pada hari tanggal yang sudah tidak diingat lagi pada bulan Nopember 2017 sampai dengan hari Kamis tanggal 27 September 2018 sekira pukul 21.00 WIB, bertempat di Konter Pulsa dan token listrik yang beralamat di Dusun Kecubung Rt/Rw 001/004 Desa Terbanggi Besar Kecamatan Terbanggi Besar Kabupaten Lampung Tengah; Bahwa Terdakwa telah memalsukan Surat Keterangan Catatan Kepolisian (SKCK) yang Terdakwa rubah atau perpanjang tanggalnya; Bahwa pada saat ditangkap saat itu, Terdakwa sedang menscaner dan meng-edit atau mengubah Surat Keterangan Catatan Kepolisian (SKCK) yang diterbitkan dari Kepolisian Resort Lampung Tengah dan ditandatangani Kasat Intelkam HERU SULISTYANANTO, S.H; Bahwa alat yang Terdakwa gunakan untuk mengubah Surat Keterangan Catatan Kepolisian (SKCK) 
dengan menggunakan alat 1 (satu) Unit printer Scaner Merek EPSON type L360 warna hitam, yang digunakan untuk menscaner dan printing, 1 (satu) Unit Note Book Merek ADVAN seri Pin-46125 warna biru dengan kondisi tanpa keyboard dan tanpa tutup hardisck, berikut casannya, 1 (satu) Unit Keyboard External Merk Votre warna hitam dan 1 (satu) Unit Mose Merk Votre warna hitam;

Bahwa cara Terdakwa melakukannya diawali Terdakwa melakukan/menscan asli lembar Surat Keterangan Catatan Kepolisian (SKCK) yang diterbitkan dari Kepolisian Resor Lampung Tengah dengan menggunakan 1 (satu) unit printer Scaner Merek EPSON type L360 warna hitam yang telah terkoneksi dengan 1 (satu) unit Note Book Merek ADVAN yang dapat dibuka pada file My Documen di data My Picture, yang kemudian diedit menggunakan program photoshop. Adapun yang edit atau diubah adalah : a. Pada nomor seri SKCK (yang terletak di sebelah kanan atas); b. Pada nomor SKCK (yang terletak di bagian tengah atas dibawah logo Polri); c. Pada kolom identitas diri; d. Pada kolom masa aktif; e. Pada kolom tanggal dikeluarkan; f. Pada foto pemohon; Setelah selesai di lakukan peng-editan menggunakan photoshop maka selanjutnya dicetak (print- out) dan hasilnya berwarna hitam putih;

Bahwa Terdakwa melakukan perbuatan memalsu Surat Keterangan Catatan Kepolisian (SKCK) tersebut sudah sejak bulan November 2017. Terdakwa mendapatkan asli lembar Surat Keterangan Catatan Kepolisian (SKCK) adalah dari orang-orang yang minta tolong kepada Terdakwa, namun tidak semua asli melainkan adapula yang berupa foto copy yang dilegalisir.Keberadaan asli Surat Keterangan Catatan Kepolisian (SKCK) yang asli tersebut ada pada Terdakwa dan adapula yang diambil oleh orang yang meminta tolong;

Bahwa sejak bulan November 2017 sampai dengan Terdakwa tertangkap oleh pihak Kepolisian Resort Lampung Tengah pada tanggal 27 September 2018 yang sudah tercetak lebih kurang sebanyak 45 (empat puluh lima) lembar untuk 45 (empat puluh lima) orang; Bahwa setelah Terdakwa lihat, Terdakwa baca serta Terdakwa amati, bahwa barang bukti tersebut merupakan barang bukti yang ditemukan ada pada Terdakwa yang Terdakwa letakan di atas meja kerja Terdakwa. barang bukti tersebut merupakan hasil cetakan SKCK dari editan yang Terdakwa lakukan, namun terdapat beberapa kesalahan sehingga Terdakwa perbaiki dan yang sudah benar diserahkan kepada orang yang minta dieditkan serta yang salah Terdakwa tumpuk diatas meja Terdakwa dan adapula yang sudah Terdakwa buang; Bahwa Terdakwa mengetahui hal tersebut dikarenakan kebanyakan mereka yang minta dibuatkan tersebut menyampaikan kepada Terdakwa untuk dijadikan sebagai persyaratan bekerja di PT. GGPC Humas Jaya;

Bahwa berdasarkan fakta-fakta juridis yang terungkap di persidangan menunjukkan bahwa perbuatan materiil terdakwa pada waktu itu adalah terdakwa telah Dengan sengaja Membuat secara tidak benar atau memalsu surat yang dapat menimbulkan sesuatu hak, yang diperuntukan sebagai bukti daripada 
sesuatu hal, dengan maksud untuk memakai atau menyuruh orang lain pakai surat tersebut seolah-olah isinya benar dan tidak dipalsu, jika pemakai tersebut dapat menimbulkan kerugian dan terdakwa mengetahui bahwa perbuatan Terdakwa tersebut salah, dengan demikian unsur kedua dari pasal ini telah terpenuhi ;

Bahwa terhadap barang bukti yang diajukan di persidangan untuk selanjutnya dipertimbangkan sebagai berikut: Menimbang, bahwa barang bukti berupa 1 (satu) unit printer scaner merek Epson type L360 warna hitam, 1 (satu) unit Note Book merek Advan seri P-46125 warna biru dengan kondisi tanpa keyboard dan tanpa tutup hardisck berikut casanya, 1 (satu) unit Keyboard External merek Votre warna hitam dan 1 (satu) unit Mose merek Votre warna hitam, adalah milik Terdakwa, maka terhadap barang bukti dikembalikan kepada Terdakwa M Solikhin Bin Lasimin; Bahwa barang bukti berupa : 1 (satu) lembar Surat Keterangan Catatan Kepolisian Nomor SKCK /YANMAS/014/I/2018/INTELKA M, tanggal 05 Januari 2018, dengan identitas yang tertera didalamnya nama Asni Malasari, Perempuan, Indonesia, Islam, Komering Agung, 08 Nopember 1991, Dusun 02 RT/RW 004/002 KP Gunung Agung, Kec. Terusan Nunyai Kab. Lampung Tengah, tertempel foto berlayar belakang warna biru; - 1 (satu) lembar Surat Keterangan Catatan Kepolisian Nomor SKCK /YANMAS/1198/XII/2016/INTEL KAM, dengan kondisi ditempel dengan potongan kertas bertulis 06 April 2018 (pada kolom kolom berlaku), 06 Oktober 2018 (pada kolom sampai dengan) 06 April 2018 (pada kolom dikeluarkan pada tanggal), dengan logo Polri berwarna kuning emas dan dengan seri nomor : 08-110579. dengan identitas yang tertera didalamnya nama Mila Ramanda, Perempuan, Indonesia, Islam, Bumi Ratu, 29 Agustus 1998, Dusun 01 RT/RW 002/001 Bumi Ratu Nuban Kab. Lampung Tengah, terdapat foto berlayar belakang warna merah; - 1 (satu) lembar Surat Keterangan Catatan Kepolisian Nomor SKCK /YANMAS/03/I/2013/INTELKAM , tanggal 17 Januari 2013, dengan logo Polri berwarna kuning emas, dengan nomor seri nomor : 08- 155574 dengan identitas yang tertera didalamnya nama Susi Yanti, Perempuan, Indonesia, Islam, Mataram Udik, 27 April 1985, Kampung Mataram Udik RT/RW 04/01 Kec. Bandar Mataram Kab. Lampung Tengah, terdapat foto berlayar belakang warna merah; - 1 (satu) lembar Surat Keterangan Catatan Kepolisian Nomor SKCK berlegalisir dan berwarna hitam putih, seri nomor : 08-095691 dengan nomor SKCK /YAMAS/03/I/2013/INTELKAM, tanggal 26 Juni 2018 dengan nama Woro Septia Ningsih; - 1 (satu) lembar Surat Keterangan Catatan Kepolisian Nomor SKCK berlegalisir dan berwarna hitam putih, seri nomor : 08-095690 dengan nomor SKCK /YAMAS/993/VI/2018/INTELKA M, tanggal 10 Juli 2018 dengan nama Safrizal; - 1 (satu) lembar Surat Keterangan Catatan Kepolisian Nomor SKCK berlegalisir dan berwarna hitam putih, seri nomor : 08-095681 dengan nomor SKCK /YAMAS/993/VI/2018/INTELKA M, tanggal 30 Juni 2018 dengan nama I Made Buda Wicaksana; - 1 (satu) lembar Surat Keterangan Catatan Kepolisian 
Nomor SKCK berlegalisir dan berwarna hitam putih, seri nomor : 08-180684 dengan nomor SKCK /YAMAS/15327/VI/2018/INTELK.

AM, tanggal 26 Juni 2018 dengan nama Fitri Wulandari; - 1 (satu) lembar Surat Keterangan Catatan Kepolisian Nomor: SKCK/YANMAS/15327/IX/2017/I NTELKAM, tanggal 26 September 2017, dengan logo Polri warna kuning emas, dengan seri nomor : 08-180684 dengan identitas yang tertera didalamnya nama Fitri Wulandari, Perempuan, Indonesia, Islam, Terusan Nunyai Kab. Lamteng, tertempel foto berlayar belakang warna merah; Telah disita secara sah dan patut dan menjadi satu kesatuan dalam perkara ini, maka terhadap barang bukti Tetap terlampir dalam berkas perkara;

Selain syarat sehat jasmani dan rohani berdasarkan penjelasan dari Iptu Nano Taryono selaku penyidik polres Lampung Tengah dan Elva Yulita selaku Jaksa pada Kejaksaan Negeri Gunung Sugih bahwa dalam dakwaan dan tuntutan pidana, terdakwa harus memenuhi syarat-syarat untuk dapat dipidana yaitu perbuatan terdakwa telah memenuhi unsur-unsur perbuatan pidana yang tertuang dalam pasal yang didakwakan yaitu Pasal 263 ayat (1) KUHP yang berbunyi "Barang siapa membuat surat palsu atau memalsukan surat yang dapat menimbulkan sesuatu hak, perikatan atau pembebasan hutang, atau yang diperuntukkan sebagai bukti daripada sesuatu hal dengan maksud untuk memakai atau menyuruh orang lain memakai surat tersebut seolah-olah isinya benar dan tidak dipalsu, diancam jika pemakaian tersebut dapat menimbulkan kerugian, karena pemalsuan surat, dengan pidana penjara paling lama enam tahun".

Penegakan hukum pidana pada dasarnya adalah merupakan penegakan kebijakan hukum melalui tiga tahap: a. Tahap formulasi, yaitu tahap penegakan hukum in abstracto oleh pembuat undang-undang yang disebut juga legislatif atau merupakan tahap strategis dalam penanggulangan kejahatan dan proses fungsionalisasi hukum.tahap. formulasi juga tahap yang menjadi dasar atau pedoman bagi tahap fungsionalisasi berikutnya.

b. Tahap aplikasi, yaitu merupakan tahap penerapan pidana oleh aparat penegak hukum atau badan hukum mulai dari kepolisian sampai dengan pengadilan. Tahap ini disebut juga dengan tahap yudikatif. c. Tahap eksekusi,yaitu tahap pelaksanaan dari hukum pidana secara konkrit yang ditegakkan oleh penegak hukumsebagai pelaksana pidana. Barda Nawawi Arief menambahkan bahwa tujuan tersebut dapat diidentifikasikan hal hal pokok sebagai berikut: a. Pencegahan dan penanggulangan kejahatan menujang tujuan (goal), kesejahteraan masyarakat/ social welfare (SW) dan perlindungan masyarakat/ Social Defence (SD). Aspek SW dan SD sangat penting adalah aspek kesejahteraan/ perlindungan masyarakat yang bersifat immateri, terutama nilai kepercayaan, kebenaran/ kejujuran/ keadilan. b. Pencegahan dan penanggulangan kejahatan harus dilakukan dengan pendekatan integral, ada keseimbangan sarana penal dan nonpenal. Dilihat dari sudut politik kriminal, kebijakan paling stategis melalui 
sarana non penal karena lebih bersifat preventif dan kebijakan penal memiliki kelemahan/ keterbatasan (yaitu bersifat fragmentaris/ simplitis/ tidak struktural fungsional: simptomatik/ tidak kausatif/ tidak eliminatif : indifidualistik atau "avender-orientid/ tidak victim- orientid": lebih bersifat represif/ tidak preventif : harus didukung oleh infrastruktur dengan biaya tinggi) c. Pencegahan dan penanggulangan kejahatan dengan sarana penal merupakan penal policy atau penal law and forcement policy yang fungsionalisasi atau operasionalisasinya melalui beberapa tahap yakni tahap formulasi, tahap aplikasi dan tahap eksekusi. Dengan adanya tahap formulasi, maka upaya pencegahan dan penanggulangan kejahatan bukan hanya tugas aparat penegak hukum, tetapi juga aparat pembuat hukum(aparatlegislatif) : bahkan kebijakan legislatif merupakan tahap yang paling stategisdari "penal policy". Karena itu, kesalahan/ kelemahan kebijakan legislatif merupakan kesalahan strategis yang dapat menjadi penghambat upaya pencegahan dan penanggulangan kejahatan pada tahap aplikasi dan eksekusi.

Dalam teori hukum pidana, bentuk kesalahan terdiri dari 2 (dua) macam, yaitu Sengaja (dolus) dan kelalaian (culva) di syaratkan bahwa delik-delik itu harus dilakukan dengan sengaja, kesengajaan itu hanya dapat ditujukan kepada : a. Tindakan-tindakan, baik tindakan untuk melakukan sesuatu maupun tindakan untuk tidak melakukan sesuatu. b. Tindakan untuk menimbulkan suatu akibat yang telah dilarang oleh undang- undang. c. Dipenuhi unsur-unsur selebihnya dari delik yang bersangkutan.

Berdasarkan uraian fakta persidangan maka Majelis Hakim memutuskan berdasarkan Pasal 263 ayat (1) KUHP, Undang-Undang Nomor 8 tahun 1981 KUHAP, serta ketentuan Hukum dan peraturan perundang- undangan lain yang berkaitan dengan perkara ini, maka Majelis Hakim dalam amar putusannya memutuskan 1. Menyatakan Terdakwa M. SOLIKHIN Bin LASIMIN telah terbukti secara sah dan meyakinkan bersalah melakukan tindak pidana "Pemalsuan Surat" ; 2. Menjatuhkan pidana terhadap terdakwa M. SOLIKHIN Bin LASIMIN oleh karena itu dengan pidana penjara selama 1 (satu) tahun dan 2 (dua) bulan; 3. Menetapkan masa penangkapan dan penahanan yang telah dijalani terdakwa di kurangkan seluruhnya dari pidana penjara yang dijatuhkan ; 4. Menetapkan agar terdakwa tetap berada dalam tahanan ; 5 . Menetapkan barang bukti berupa : 1 (satu) unit printer scaner merek Epson type L360 warna hitam; - 1 (satu) unit Note Book merek Advan seri P-46125 warna biru dengan kondisi tanpa keyboard dan tanpa tutup hardisck berikut caranya; - 1 (satu) unit Keyboard External merek Votre warna hitam; - 1 (satu) unit Mose merek Votre warna hitam; Dikembalikan kepada Terdakwa M SOLIKHIN Bin LASIMIN; - 1 (satu) lembar Surat Keterangan Catatan Kepolisian Nomor SKCK /YANMAS/014/I/2018/INTELKA M, tanggal 05 Januari 2018; - 1 (satu) lembar Surat Keterangan Catatan Kepolisian Nomor SKCK/YANMAS/1198/XII/2016/I NTELKAM, dengan kondisi ditempel dengan potongan kertas bertulis 06 April 2018 ; - 1 (satu) lembar Surat Keterangan 
Catatan Kepolisian Nomor SKCK/YANMAS/03/I/2013/INTE LKAM, tanggal 17 Januari 2013; - 1 (satu) lembar Surat Keterangan Catatan Kepolisian Nomor SKCK berlegalisir dan berwarna hitam putih, seri nomor : 08-095691 dengan nomor SKCK/YAMAS/03/I/2013/INTEL KAM, tanggal 26 Juni 2018 dengan nama Woro Septia Ningsih; - 1 (satu) lembar Surat Keterangan Catatan Kepolisian Nomor SKCK berlegalisir dan berwarna hitam putih, seri nomor : 08-095690 dengan nomor SKCK/YAMAS/993/VI/2018/INT ELKAM, tanggal 10 Juli 2018 dengan nama Safrizal; - 1 (satu) lembar Surat Keterangan Catatan Kepolisian Nomor SKCK berlegalisir dan berwarna hitam putih, seri nomor : 08-095681 dengan nomor SKCK/YAMAS/993/VI/2018/INT ELKAM, tanggal 30 Juni 2018 dengan nama I Made Buda Wicaksana; - 1 (satu) lembar Surat Keterangan Catatan Kepolisian Nomor SKCK berlegalisir dan berwarna hitam putih, seri nomor : 08-095691 dengan nomor SKCK/YAMAS/993/VI/2018/INT ELKAM, tanggal 26 Juni 2018 dengan nama Pardo Susanto; - 1 (satu) lembar Surat Keterangan Catatan Kepolisian Nomor SKCK berlegalisir dan berwarna hitam putih, seri nomor : 08095691 dengan nomor SKCK/YAMAS/993/VI/2018/INT ELKAM, tanggal 26 Juni 2018 dengan nama Saritun; - 1 (satu) lembar Surat Keterangan Catatan Kepolisian Nomor SKCK berlegalisir dan berwarna hitam putih, seri nomor : 08-095691 dengan nomor SKCK /YAMAS/993/VI/2018/INTELKA M, tanggal 30 Juni 2018 dengan nama Nurmansyah; - 1 (satu) lembar Surat Keterangan Catatan Kepolisian Nomor: SKCK/YANMAS/15327/IX/2017/I NTELKAM, tanggal 26 September 2017; 6. Membebankan terdakwa untuk membayar biaya perkara sejumlah Rp. 2.000,00 (dua ribu rupiah);

Berdasarkan uraian hasil penelitian tersebut diatas maka fakta-fakta yang diperoleh dalam penelitian dilapangan sesuai dengan teori yang dikemukakan oleh Roeslan Saleh yang menyatakan bahwa pertanggungjawaban pidana atau kesalahan menurut hukum pidana, terdiri atas tiga syarat yaitu :

Kemampuan bertanggung jawab atau dapat dipertanggung jawabkan dari si pembuat. b. Adanya perbuatan melawan hukum yaitu suatu sikap psikis si pelaku yang berhubungan dengan kelakuannya yaitu : Disengaja dan Sikap kurang hatihati atau lalai (kealpaan). c. Tidak ada alasan pembenar atau alasan yang menghapuskan pertanggung jawaban pidana bagi si pembuat. Juga didukung oleh pendapat Moeljatno yang menyatakan bahwa Menurut jenisnya kesengajaan mempunyai 3 (tiga) jenis, yaitu : sengaja dengan maksud, sengaja dengan kepastian dan sengaja dengan tujuan. a. Sengaja dengan maksud (dolesdirektus) Sengaja dengan maksud adalah bentuk yang paling sederhana karena dalam pengertiannya memang pelaku menghendaki perbuatan tersebut, baik kelakuan maupun akibat/keadaan yang menyertainya. Menurut Vos dalam bukunya P.A.F. Lamintang bahwa yang dinyatakan sengaja dengan maksud, apabila pembuat menghendaki akibat perbuatannya. la tidak pernah melakukan perbuatannya 
apabila pembuat mengetahui bahwa akibat perbuatannya tidak akan terjadi." b. Sengaja dengan kepastian.

Menurut Moeljatno bahwa sengaja dengan kepastian atau sengaja dengan kesadaran tentang kepastian (opzet met bewust theid van zekerheid of noodzakelijkheid) perkataan "zeker" atau "pasti", sedangkan "bewust" atau "sadar" berarti sadar akan kepastian. Jadi dapat dijelaskan apa yang dilakukannya (tersangka) dilandasi dengan kesadaran akan timbulnya akibat lain dari padaakibat yang memang diinginkannya. c. Sengaja dengan tujuan Menurut Moeljatno yaitu sengaja dengan tujuan atau sengaja dengan kesadaran kemungkinan sekali terjadi (opzet met Ivaarschynly kjeidsbeustzyri) dapat diberikan bahwa si pelaku mengetahui dampak dari perbuatan atau mengetahui dari perbuatannya.

\section{PENUTUP}

\section{A. Kesimpulan}

1. Faktor penyebab pelaku melakukan tindak pidana menggandakan surat palsu untuk bekerja Di PT Great Giant Pineapple Humas jaya pada Perkara Nomor : 403/Pid.B/2018/PN.Gns yaitu Niat Pelaku, Faktor Pendidikan yang rendah, Faktor Kebutuhan Ekonomi, dan Faktor rendahnya Moral dan Pengetahuan Agama 2. pertanggungjawaban pelaku tindak pidana menggandakan surat palsu untuk bekerja dalam putusan Nomor : 403/Pid.B/2018/PN.Gns yang disesuaikan dengan amar putusan Majelis Hakim bahwa pelaku terbukti secara sah dan meyakinkan melakukan tindak pidana menggandakan surat palsu untuk bekerja dengan pidana penjara selama 1 (satu) tahun dan 2 (dua) bulan.

\section{B. Saran}

Hendaknya Jaksa Penuntut Umum harus teliti dan cermat dalam menyusun surat dakwaan, mengingat surat dakwaan merupakan dasar bagi hakim untuk menjatuhkan atau tidak menjatuhkan pidana terhadap pelaku yang dihadapkan di muka persidangan. 2. Perlunya peningkatan peran serta masyarakat Kabupaten Gunung Sugih untuk mendukung upaya penanggulangan dan pemberantasan penggandaan surat palsu yang di lakukan oleh Polres Gunung Sugih 


\section{DAFTAR PUSTAKA}

Chazawi, 2002. Pelajaran Hukum Pidana I, PT. Rajagrafindo Persada, Jakarta, \Andi Hamzah, 2004,Hukum Acara Pidana Indonesia, Sinar Grafika, Jakarta, Edisi Revisi

Bambang Purnomo, 1985,Asas-Asas Hukum Pidana, Ghalia Indonesia

Barda Nawawi Arief, 2008. Bunga Rampai Kebijakan Hukum Pidana, Kencana, Semarang.

C.S.T Kansil dan Christine S.T Kansil, 2007,Pokok-Pokok Hukum Pidana, PT Pradnya Paramitha, Jakarta

Lawrence M. Friedman, 1993, Teori dan Filsafat hukum: Telaah kritis atasi TeoriTeori Hukum (Susunan I), judul asli Legal Theory, cetakan kedua, PT. RajaGrafindo Persada, Jakarta,

Leden Marpaung, 1991. Unsur - Unsur Perbuatan Yang dapat Dihukum (Delik) Jakarta, Sinar Grafika,

Undang-Undang Dasar 1945 dan Hasil Amandemen.

Undang-Undang Nomor 2 Tahun 2002 tentang Kepolisian Negara Republik Indonesia.

Undang-Undang Nomor 4 Tahun 2004 jo Undang-Undang Nomor 48 Tahun 2009 tentang Kekuasaan Kehakiman Republik Indonesia.

Undang-Undang Nomor 16 Tahun 2004 tentang Kejaksaan Republik Indonesia.

Undang-Undang Nomor 8 Tahun 1981 tentang Hukum Acara Pidana (KUHAP) 


\section{PEDOMAN PENULISAN \\ JURNAL PRANATA HUKUM}

1. Naskah bersifat orisinil, baik berupa hasil riset atau tinjauan atas suatu permasalahan hukum yang berkembang di masyarakat (artikel lepas), dimungkinkan juga tulisan lain yang dipandang memberikan kontribusi bagi pengembangan ilmu hukum.

2. Penulisan terdiri atas beberapa bab penulisan hasil penelitian terdiri dari $3 \mathrm{BAB}$, yaitu ;

BAB I. PENDAHULUAN (Latar Belakang dan Rumusan Masalah) BAB II. PEMBAHASAN (Kerangka Teori dan Analisis), dan BAB III. PENUTUP (Kesimpulan dan Saran).

3. Tulisan menggunakan bahasa indonesia maupun bahasa inggris yang memenuhi kaidah bahasa yang baik dan benar,tulisan menggunakan bahasa indonesia disertai abstrak dalam bahasa inggris (200 kata) dan Kata kunci, ketentuan ini berlaku sebaliknya.

4. Setiap kutipan harus menyebutkan sumbernya dengan format footnote. Sumber kutipan harus memuat nama pengarang, tahun penerbitan, judul buku, nama penerbit, kota penerbit, dan halaman. Contoh : Bagir Manan. 1994. Hubungan Antara Pemerintah Pusat dan Daerah Menurut UUD 1945. Pustaka Sinar Harapan. Jakarta. 1994, hlm. 19. Untuk artikel dari internet dengan susunan: nama penulis, judul tulisan digaris bawah, alamat website, waktu download/unduh.

5. Naskah harus disertai dengan daftar pustaka atau referensi ,terutama yang digunakan sebagai bahan acuan langsung. Daftar pustaka dan referensi bersifat alfabetis dengan format; nama pengarang, judul buku, nama penerbit, kota terbit, dan tahun penerbitan. Contoh: Bagir Manan. 1994. Hubungan Antara Pemerintah Pusat dan Daerah Menurut UUD 1945. Pustaka Sinar Harapan. Jakarta.

6. Panjang tulisan antara 15-25 halaman, font cambria dengan 1,15 spasi. Dalam hal hal tertentu berlaku pengecualian panjang tulisan.

7. Naskah disertai nama lengkap penulis, alamat e-mail dan lembaga tempat berafiliasi saat ini, dan hal lain yang dianggap penting. 
Jurnal PRANATA HUKUM dimaksudkan sebagai media komunikasi, edukasi, dan informasi ilmiah bidang ilmu hukum khususnya, dan ilmu sosial pada umumnya. Sajian dan kemasan diupayakan komunikatif melalui bahasa ilmiah.

Redaksi mengundang semua elemen masyarakat baik civitas akademika, praktisi, lembaga masyarakat, maupun perorangan yang berminat terhadap bidang hukum untuk berpartisipasi mengembangkan gagasan, wawasan, dan pengetahuan melalui tulisan untuk dimuat dalam jurnal ini.

Melalui PRANATA HUKUM diharapkan terjadi proses pembangunan dan pengembangan bidang hukum sebagai bagian penting dari rangkaian panjang proses memajukan masyarakat bangsa.
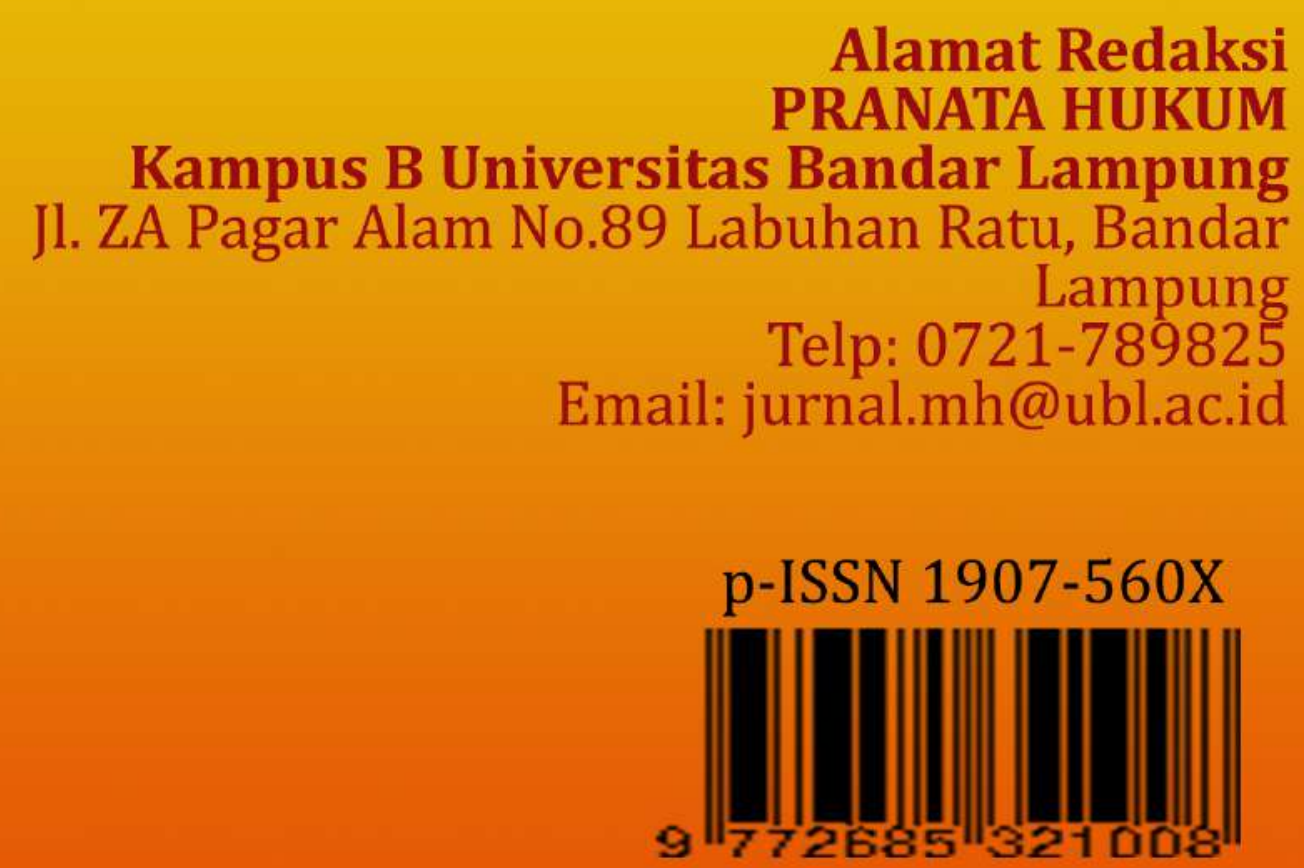